\title{
Amyloid Fibril-Directed Therapy
}

National Cancer Institute

\section{Source}

National Cancer Institute. Amyloid Fibril-Directed Therapy. NCI Thesaurus. Code

C161823.

Any therapeutic modality that directly blocks the formation of amyloid fibril formation or, especially, those that directly target the accumulated proteins for clearance. 